\title{
Leptin is suppressed during infusion of recombinant human insulin-like growth factor I (rhIGF I) in normal rats
}

\author{
M. Böni-Schnetzler, C. Hauri, J. Zapf \\ Division of Endocrinology and Diabetology, Department of Medicine, University Hospital, Zurich, Switzerland
}

\begin{abstract}
Summary To examine whether insulin-like growth factor I (IGF I) or growth hormone $(\mathrm{GH})$ influences leptin in vivo we measured leptin mRNA in epididymal fat pads and serum leptin of normal rats infused subcutaneously for 6 days with recombinant human (rh)IGF I (1 mg/day), rhGH (200 mU/day), or vehicle. In addition, we determined fat pad weight and food consumption as well as IGF I, insulin, glucose, non-esterified fatty acid (NEFA), glycerol, $\beta$-hydroxybutyrate and triglyceride (TG) serum concentrations. Food intake was identical during all three treatments. RhIGF I but not rhGH raised IGF I serum concentrations, reduced fat pad weight $(60.3 \pm 7.4 \%$ of control rats, $p=0.019)$, and suppressed leptin mRNA $(38.8 \pm 11.9 \%$ of control rats, $p=0.002)$, serum leptin $(51.6 \pm 10.5 \%$ of control rats, $p=0.0028)$ and serum triglycerides $(39.3 \pm 8.0 \%$ of control rats, $\left.p=2.6 \times 10^{-6}\right)$. Both rhIGF $\mathrm{I}$ and $\mathrm{rhGH}$ reduced non-esterified fatty acids (NEFA) $(p=0.00001$ and 0.0007 , respectively), whereas serum glycerol, $\beta-\mathrm{OH}$ butyrate and glucose concentrations remained unchanged. Serum insulin concentrations during rhIGF
\end{abstract}

I were lower than during rhGH infusion and correlated with leptin mRNA $(r=0.589, p=0.016)$ and fat pad weight $(r=0.643, p=0.007)$. Reduction of adipose tissue mass and suppression of leptin by IGF I appear to be due to reduced circulating insulin leading to enhanced fat mobilization and NEFA oxidation as well as to increased gluconeogenesis from glycerol. In contrast, decreased NEFA concentrations during rhGH in the presence of unchanged fat pad weight, serum glycerol and triglycerides might result from more efficient re-esterification of released fatty acids within the triglyceride-fatty acid cycle. The results also show that exogenously infused IGF I and GH act on lipid metabolism by different mechanisms and suggest an IGF-independent, probably direct, metabolic effect of GH. Finally, in agreement with previous studies in $\mathrm{GH}$-infused hypophysectomized rats, it appears unlikely that $\mathrm{GH}$ regulates leptin in the rat. [Diabetologia (1999) 42: 160-166]

Keywords Adipose tissue, food consumption, triglycerides, free fatty acids.
Leptin (ob) which was isolated by positional cloning from the genetically obese ob/ob mouse [3] is a 16 $\mathrm{kDa}$ hormone which is nearly exclusively produced by adipocytes (although production by the placenta

Received: 21 July 1998 and in revised form: 5 October 1998

Corresponding author: J. Zapf, M.D., Division of Endocrinology and Diabetology, Department of Medicine, University Hospital, Rämistrasse 100, 8091 Zurich, Switzerland Abbreviations: IGF I, Insulin-like growth factor I; TG, triglycerides; GH, growth hormone; rh, recombinant human; NEFA, non-esterified fatty acids. and skeletal muscle has recently been reported [1, 2]). In humans high adiposity, hyperinsulinaemia and insulin resistance are associated with increased serum leptin concentrations [4-8]. In rodents, leptin controls food intake, satiety and body weight [9-12]. Insulin appears to be the most important regulator of leptin synthesis in rodents [13-15]. It directly upregulates leptin expression in vivo and in vitro. In conditions characterized by low insulin concentrations such as streptozotocin-induced diabetes or fasting, leptin mRNA expression and serum leptin concentrations were found to be suppressed $[16,17]$. Administration of insulin or refeeding normalized leptin con- 
centrations $[13,16,17]$. In vitro a direct stimulatory effect of insulin on leptin mRNA expression and leptin secretion has been shown in adipocyte cell lines and in primary adipocytes cultures [13, 15, 17-19].

In a previous study in which we examined whether $\mathrm{GH}$ affects leptin expression, we showed that hypophysectomized rats have suppressed fat pad leptin mRNA and nearly undetectable serum insulin concentrations and that neither could be restored by rhGH treatment [20]. In contrast, infusion of rhIGF I further suppressed the already low leptin mRNA in fat pads of hypophysectomized rats. Similarly, serum leptin concentrations and insulin secretion were suppressed by rhIGF I infusion in GH-deficient human subjects [21].

In vitro no direct effect of IGF I on leptin synthesis was observed in adipocytes isolated from normal rats [18]. Therefore and because our previous experiments were carried out in GH-deficient rats, we examined the in vivo effect of infused rhIGF I on leptin in normal rats and compared it with the effect of infused $\mathrm{rhGH}$.

\section{Materials and methods}

Animals. All animal experiments were approved by the Institutional Animal Welfare Committee. We infused normal male Tif RAI rats (170-190 $\mathrm{g}$ at the beginning of the experiment) for 6 days with $1 \mathrm{mg}$ per day of rhIGF I (Novartis, Basel, Switzerland) in $0.1 \mathrm{~mol} / 1$ acetic acid or with $200 \mathrm{mU}$ per day of rhGH (Nordisk, Gentofte, Denmark) or with vehicle ( $0.1 \mathrm{~mol} / \mathrm{l}$ acetic acid) using Alzet miniosmotic pumps (model 2001, Alza Corp., Palo Alto, Calif., USA) implanted subcutaneously. Food and water intake as well as body weight were measured daily in the morning. Hoarding or dispersion of food was carefully checked and was not observed. After 6 days of infusion, rats were anaesthetized with Innovar Vet (Pitman Moore, Washington Crossing, N.J., USA, $0.2 \mathrm{ml} / 100$ g body weight) and killed by aortic puncture. After clotting on ice, blood was centrifuged for $30 \mathrm{~min}$ at $3000 \mathrm{~g}$ and $4{ }^{\circ} \mathrm{C}$, and serum was stored at $-20^{\circ} \mathrm{C}$. Epididymal fat pads were removed, weighed, immediately frozen in liquid nitrogen and stored at $-80^{\circ} \mathrm{C}$.

Preparation of a rat leptin DNA probe. Total rat fat pad RNA was reverse transcribed using oligo(dT) as a primer and the Superscript reverse transcriptase (GIBCO BRL, Basel, Switzerland) according to the manufacturer's instructions. The rat cDNA was subjected to polymerase chain reaction (PCR) (kit from Boehringer Mannheim, Germany) using two oligonucleotides complementary to the mouse leptin cDNA [22]. The resulting 404 bp rat leptin cDNA fragment was separated by low melting agarose gel electrophoresis and extracted by agarase digestion (Boehringer Mannheim, Germany). Before hybridization, the fragment was labelled with $\left(\alpha-{ }^{32} \mathrm{P}\right)$ deoxy-CTP ( $3000 \mathrm{Ci} / \mathrm{mmol}$, Amersham International, Amersham, UK) by random primer extension (kit from Boehringer Mannheim, Germany).

Total RNA isolation and Northern blotting. Total RNA was extracted from frozen fat pads by a standard $\mathrm{CsCl}$ centrifugation method [23] with the following modification: after homogeni- zation a low speed centrifugation step was included to band the fat at the top of the homogenate. The underlying homogenate was then removed and processed as described [23]. $10 \mu \mathrm{g}$ of total RNA was separated in $1 \%$ agarose gel containing $2 \mathrm{~mol} / \mathrm{l}$ formaldehyde. The amount of RNA loaded and its intactness were judged by visual inspection of ethidium bromide-stained gels. Distinct bands above the two ribosomal RNA bands are adequate indicators for intact RNA, whereas smearing (not observed on our blots) points to partial degradation of RNA. Size-fractionated RNA was transferred to Nylon membranes (Hybond-N, Amersham, UK) by capillary blotting and crosslinked by UV-radiation [24]. Filters were prehybridised and subsequently hybridised with the radioactive $404 \mathrm{bp}$ rat cDNA fragment and washed as described [25]. The blots were exposed overnight to Kodak X-Omat films (Eastman Kodak, Rochester, N. Y., USA) in the presence of a Cronex lightening plus enhancer screen (Eastman Kodak) and the optical densities of the $4.5 \mathrm{~kb}$ bands of leptin mRNA were determined using a BIO RAD densitometre, model GS 700 (BioRad Laboratories, Richmond, Calif., USA).

Determination of NEFA, glycerol, $\beta$-hydroxybutyrate, triglycerides (TG), glucose, leptin, insulin and IGF I. Serum NEFA concentrations were determined with a commercial kit (Wako Chemicals, Neuss, Germany) and serum insulin and rat leptin with a radioimmunoassay from LINCO (Labodia SA, Yens, Switzerland) according to the protocols provided by the suppliers. Serum glyerol was determined by Eggstein and Kreutz's method [26]. Triglyceride and $\beta$-hydroxybutyrate were determined in an auto-analyzer by the Institute of Clinical Chemistry of our hospital. Serum glucose was measured by a glucose analyzer (Beckman, Fullerton, Calif., USA).

Exogenous or endogenous serum IGF I was determined by two different radioimmunoassays (RIAs) as described previously [27, 28]. Briefly, $0.15 \mathrm{ml}$ phosphate buffered saline (PBS) $/ 0.2 \%$ human serum albumin (HSA), pH 7.4, was added to $0.1 \mathrm{ml}$ serum and the mixture was acid-treated and run on SepPak C18-cartridges (Waters, Milford, Mass., USA) according to the protocol supplied by Immunonuclear (Stillwater, Minn., USA). After reconstitution with $1 \mathrm{ml} \mathrm{PBS} / 0.2 \% \mathrm{HSA}$, all samples were assayed at three different dilutions (1:5; 1:10, 1:20) using as standards either rhIGF I for the determination of exogenously administered rhIGF I, or rat IGF (gift from Dr. M. Kobayashi, Fujisawa, Japan) for the determination of endogenous rat IGF I, and two different antisera at a final dilution of 1:2000 [27] and 1:20 000 [28], respectively. After preincubation of antiserum with standards or samples for $24 \mathrm{~h}$ at $4^{\circ} \mathrm{C}, 25-35000 \mathrm{cpm}$ of ${ }^{125} \mathrm{I}-\mathrm{IGF}$ I (Anawa, Wangen, Switzerland, specific activity $300-400 \mu \mathrm{Ci} / \mu \mathrm{g}$ ) was added to a total incubation volume of $0.4 \mathrm{ml}$. The reaction mixture was then incubated for another $24 \mathrm{~h}$ before precipitation with the second antibody (goat anti-rabbit gammaglobulin antiserum) [27].

In the human IGF I RIA, rat IGF I does not crossreact at the above dilutions. The values obtained in this RIA, therefore, reflect only the concentration of the infused rhIGF I. In the rat IGF I RIA, human IGF I crossreacts five to six times better than rat IGF I so that endogenous IGF I concentrations cannot be determined in the animals infused with rhIGF. In animals infused with $\mathrm{GH}$ and in the control animals (absence of human IGF I) the RIA values represent endogenous rat IGF I concentrations.

The sensitivity of the human IGF I RIA was $17 \mathrm{fmol} /$ tube $(0.4 \mathrm{ml})$; the intraassay variation was $\pm 6.7 \%(n=6)$, the interassay variation $\pm 11.1 \%(n=6)$. The sensitivity of the rat IGF I RIA was $0.34 \mathrm{fmol} /$ tube, the intraassay variation $\pm 5.3 \%$ $(n=10)$ and the interassay variation $\pm 10.1 \%(n=10)$. 
Statistical analysis. Statistics for the three treatment groups were done with the Student's $t$-test and the Bonferroni adjustment ( $p$-values multiplied with the number of comparisons). $P$-values $<0.05$ resulting with this adjustment were considered as statistically significant. Correlations were evaluated with linear regression analysis.

\section{Results}

Growth parameters. Control rats, rhGH- or rhIGF Itreated rats did not show any great differences in food consumption during the experiment (Table 1). The body weight at the end of the experiment was not noticeably different in control and rhIGF I treated rats, but in rhGH treated rats it was $8 \%$ lower than in control animals $(p=0.02)$ (Table 1$)$. No correlation between body weight and food intake was observed during the treatment. Despite equal food intake and body weight, fat pad weights were significantly reduced after 6 days of rhIGF I treatment to $60.3 \pm 7.4 \%(p=0.019)$ as compared with untreated control rats (Table 1). Rats treated with rhGH did not show a very different fad pad weight from control rats. Similarly, the fractional fat pad weight $(\mathrm{g} / 100 \mathrm{~g}$ body weight) was significantly lower in rhIGF Ithan in rhGH-treated $\left(p=1.68 \times 10^{-5}\right)$ or in control rats $(p=0.014)$.

Serum IGF I, insulin, glucose, FFA, glycerol, $\beta$-hydroxybutyrate and triglyceride concentrations. Endogenous rat IGF I serum concentrations did not differ in control and rhGH-treated rats (Table 1), which is consistent with our previous unpublished data and data reported by Mehls et al. [29]. In rhIGF I-treated rats, total IGF I consists of endogenous rat and exogenous rhIGF I. Determinations of exogenous rhIGF I gave a mean value of $190 \pm 14.5 \mathrm{pmol} / \mathrm{ml}$ while endogenous rat IGF could not be determined in the presence of rhIGF I (see Materials and methods). A prior infusion study with rhIGF II in normal rats $(1 \mathrm{mg} / \mathrm{rat}$ per day for 6 days) showed that endogenous IGF I was suppressed by $37 \pm 11 \%$ (Zapf, unpublished). Assuming a similar suppression by rhIGF I, we estimate the total serum IGF I concentration in rhIGF I treated rats to amount to approximately $330 \mathrm{pmol} /$ $\mathrm{ml}$. Mean serum insulin concentrations tended to be lower than in control rats during rhIGF I infusion, but the difference did not reach statistical significance. Insulin concentrations were lower during rhIGF, however, than during rhGH treatment (Table 1). In a prior 6 day infusion study with $1 \mathrm{mg} /$ rat per day of rhIGF I, serum insulin concentrations were suppressed from $0.40 \pm 0.16$ (control animals) to $0.186 \pm 0.11 \mathrm{pmol} / \mathrm{ml}(p=0.04)$ (Zapf, unpublished).

Serum glucose concentrations were not different in the three treatment groups. Non-esterified fatty acid concentrations were suppressed to $43.8 \pm 7.2 \%$ in rhIGF I-treated rats $(p=0.00001)$ and to $58.8 \pm$
$8.9 \%$ in rhGH-treated rats $(p=0.0007)$, whereas serum glycerol and $\beta$-hydroxybutyrate concentrations did not differ between the three treatment groups. Serum TG were significantly lower in rhIGF I- than in rhGH-treated $\left(p=2.6 \times 10^{-6}\right)$ and in control animals $(p=0.0008)$.

Fat pad leptin $m R N A$ and serum leptin concentrations. Northern blotting with total fat pad RNA and with the rat leptin probe showed a single transcript of approximately $4.5 \mathrm{~kb}$ (Fig. 1). A comparison of control rats with rhIGF I-treated rats showed that the latter had suppressed leptin mRNA concentrations (Table 1, Fig. 1). The mean leptin mRNA concentration of rhIGF I-treated rats was reduced to $38.8 \pm 11.9 \%$ compared with control rats $(p=0.002)$. RhGH-treated animals had $80 \pm 13.1 \%$ of the leptin mRNA found in control rats. This reduction was not statistically significant. RhIGF I infusion resulted in diminished serum leptin concentrations (51.6 \pm $10.5 \%$ of control rats, $p=0.0028)$. RhGH treated rats had $74.9 \pm 10.2 \%$ of the control animals' serum leptin concentrations (not statistically significant vs control rats).

Correlation between insulin, leptin and fat pad weight. The individual values from the three treatment groups were subjected to linear regression analysis (Figs. 2A-D). Only 16 of the 18 animals could be included in this analysis because not enough blood was obtained from one control and one GH-treated animal during aortic puncture. Regression analysis showed significant correlations between leptin mRNA and serum leptin concentrations $(r=0.948$, $p<0.0001$; Fig. 2A), between leptin mRNA and insulin $(r=0.59, p<0.05$; Fig. 2B), or serum leptin and insulin $(r=0.57 ; p=0.02)$, between fat pad weight and serum insulin $(r=0.64, p<0.01$; Fig. $2 \mathrm{C})$ and between leptin mRNA and fat pad weight $(r=0.745$, $p<0.001$; Fig. 2D) or serum leptin and fat pad weight $(r=0.75 ; p<0.001)$. No significant correlation was found between serum leptin and serum FFA concentrations.

\section{Discussion}

The key findings of this study are that rhIGF I infused at a rate of $1 \mathrm{mg}$ per day for 6 days into normal rats reduces fat pad mass and suppresses fat pad leptin mRNA and serum leptin concentrations. The suppression of serum leptin was accompanied by an increase in body weight gain per $100 \mathrm{~g}$ body weight (Table 1). These effects were not observed during rhGH infusion. As reported earlier, rhIGF I infusion in hypox rats suppressed the already decreased fat pad leptin mRNA to nearly zero [20], whereas GH treatment of the hypox animals had no effect on leptin 
Table 1. Summary of results in normal rats treated with rhIGF I ( $1 \mathrm{mg}$ per rat per day) or rhGH (200 mU per rat per day)

\begin{tabular}{|c|c|c|c|}
\hline & Control rats & rhIGF I & $\mathrm{rhGH}$ \\
\hline Body weight (g) & $231 \pm 7.6$ & $229 \pm 9.5$ & $\begin{array}{l}214 \pm 9.9 \\
\left(p_{c}=0.02\right)\end{array}$ \\
\hline Body weight gain/100 g body weight & $19.5 \pm 1.44$ & $\begin{array}{l}26.15 \pm 2.03 \\
\left(p_{c}=0.0005\right)\end{array}$ & $\begin{array}{l}18.85 \pm 1.82 \\
\left(p_{\mathrm{IGF}}=0.018\right)\end{array}$ \\
\hline Fat pad weight $(\mathrm{g})$ & $1.21 \pm 0.32$ & $\begin{array}{l}0.73 \pm 0.09 \\
\left(p_{c}=0.019\right)\end{array}$ & $1.22 \pm 0.12$ \\
\hline Fat pad weight /100 g body weight & $0.52 \pm 0.13$ & $\begin{array}{l}0.32 \pm 0.03 \\
\left(p_{c}=0.014\right)\end{array}$ & $\begin{array}{l}0.57 \pm 0.06 \\
\left(p_{\text {IGF }}=1.68 \times 10^{-5}\right)\end{array}$ \\
\hline Food intake (g/day) & $24.4 \pm 0.4$ & $24.1 \pm 0.6$ & $24.9 \pm 0.5$ \\
\hline Serum glucose $(\mathrm{mmol} / \mathrm{l})$ & $11.71 \pm 1.15$ & $10.98 \pm 0.55$ & $10.78 \pm 1.04$ \\
\hline FFA $(\mu \mathrm{mol} / 1)$ & $472 \pm 55$ & $\begin{array}{l}207 \pm 34 \\
\left(p_{\mathrm{c}}=0.00001\right)\end{array}$ & $\begin{array}{l}278 \pm 42 \\
\left(p_{\mathrm{c}}=0.0007\right)\end{array}$ \\
\hline Glycerol ( $\mu \mathrm{mol} / \mathrm{l})$ & $142 \pm 29$ & $138 \pm 27$ & $166 \pm 35$ \\
\hline$\beta$-OH butyrate $(\mu \mathrm{mol} / \mathrm{l})$ & $166 \pm 32$ & $116 \pm 46$ & $128 \pm 9$ \\
\hline Triglycerides (mmol/l) & $1.49 \pm 0.37$ & $\begin{array}{l}0.59 \pm 0.12 \\
\left(p_{c}=0.0008\right)\end{array}$ & $\begin{array}{l}1.32 \pm 0.08 \\
\left(p_{\mathrm{IGF}}=2.6 \times 10^{-6}\right)\end{array}$ \\
\hline $\begin{array}{l}\text { Rat IGF I (nmol/l) } \\
\text { Human IGF I (nmol/l) }\end{array}$ & $\begin{array}{l}222 \pm 29 \\
-\end{array}$ & $\begin{array}{l}140 \pm 24^{1} \\
190 \pm 75\end{array}$ & $\begin{array}{l}235 \pm 26 \\
-\end{array}$ \\
\hline Serum insulin $(\mathrm{nmol} / \mathrm{l})$ & $0.270 \pm 0.088$ & $0.184 \pm 0.072$ & $\begin{array}{l}0.310 \pm 0.053 \\
\left(p_{\mathrm{IGF}}=0.03\right)\end{array}$ \\
\hline $\begin{array}{l}\text { Leptin mRNA } \\
\text { (arbitrary units) }\end{array}$ & $4.95 \pm 1.41$ & $\begin{array}{l}1.92 \pm 0.58 \\
\left(p_{\mathrm{c}}=0.002\right)\end{array}$ & $3.96 \pm 0.65$ \\
\hline Serum leptin (nmol/l) & $0.172 \pm 0.039$ & $\begin{array}{l}0.089 \pm 0.378 \\
\left(p_{c}=0.0028\right)\end{array}$ & $0.129 \pm 0.018$ \\
\hline
\end{tabular}

Values are means \pm SD $(n=5-6)$; all $p$-values are after Bonferroni adjustment ( $p$ by Student's t-test multiplied with the number of comparisons, i.e. 3); significance level: $<0.05$.

$P_{\mathrm{c}}=p$ vs control animal; $P_{\mathrm{IGF}}=p$ vs IGF I; where no $p$ values are given, differences are not statistically significant.

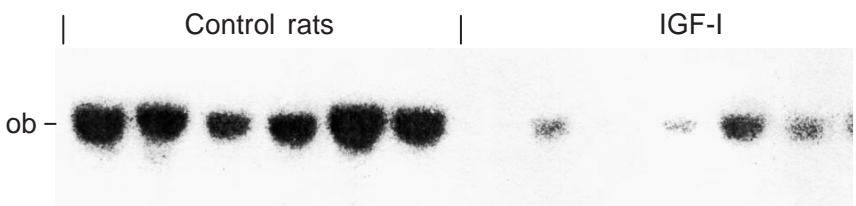

Fig. 1. Northern blot with $10 \mu \mathrm{g} / \mathrm{lane}$ of total fat pad RNA hybridized with a 404 bp rat leptin (ob) probe (see Materials and methods). The $4.5 \mathrm{~kb}$ leptin (ob) mRNA of 6 normal control rats and of 6 rhIGF I ( $1 \mathrm{mg}$ per rat per day) infused rats is shown. The blot was exposed to an X-ray film overnight

mRNA, although endogenous IGF I was restored to normal [20]. These findings suggested that infused IGF I and endogenous IGF I induced by GH - and thus in the presence of $\mathrm{GH}$ - differ in their effect on leptin. These results in normal and our previous findings in hypox rats, make it unlikely that $\mathrm{GH}$ regulates leptin in the rat. Recently it has been reported that intracerebroventricular infusion of leptin anti-serum to normal, fed female rats led to a decrease in spontaneous GH secretion [30]. In contrast, intraperitoneal infusion of leptin to fed animals did not modify spontaneous GH secretion. Only in fasted rats leptin infusion reversed the inhibitory effect of fasting on $\mathrm{GH}$ secretion. The authors concluded from these findings
${ }^{1}$ Estimated from a previous s.c. infusion study with $1 \mathrm{mg} / \mathrm{rat}$ per day of rhIGF II for 6 days in normal rats, where endogenous IGF I was suppressed by $37 \pm 11 \%$.

that leptin is a metabolic signal that regulates $\mathrm{GH}$ secretion. Our findings suggest that the reverse does not hold true, i.e., that $\mathrm{GH}$ in contrast to exogenously infused IGF I, either infused into rats with a healthy endocrine system or into rats deficient in GH does not appear to be a signal for the regulation of leptin.

Although leptin regulation differs in several respects in rodents and humans [7,8], and although $\mathrm{GH}$ secretion is regulated in an opposite fashion in these two species (e.g. GH is suppressed during fasting and stress in the rat, but increased in man), our findings in IGF I-infused hypox rats are consistent with the decrease of serum leptin in GH-deficient humans infused with IGF I [21]. In contrast to hypox rats, $\mathrm{GH}$ infusion stimulated serum leptin in these patients [21]. One of the reasons for this discrepancy might be that hypox rats lack all pituitary hormones and have low serum insulin concentrations, which did not increase much during GH treatment [20]. In contrast, $\mathrm{GH}$-deficient patients received hormone replacement therapy (except GH) and they had normal serum insulin and C-peptide levels which further increased with GH treatment [31]. Thus, the effect of $\mathrm{GH}$ on leptin in GH-deficient humans might be due to the stimulation of insulin secretion or the replacement of lacking hormones or both. Leptin suppres- 

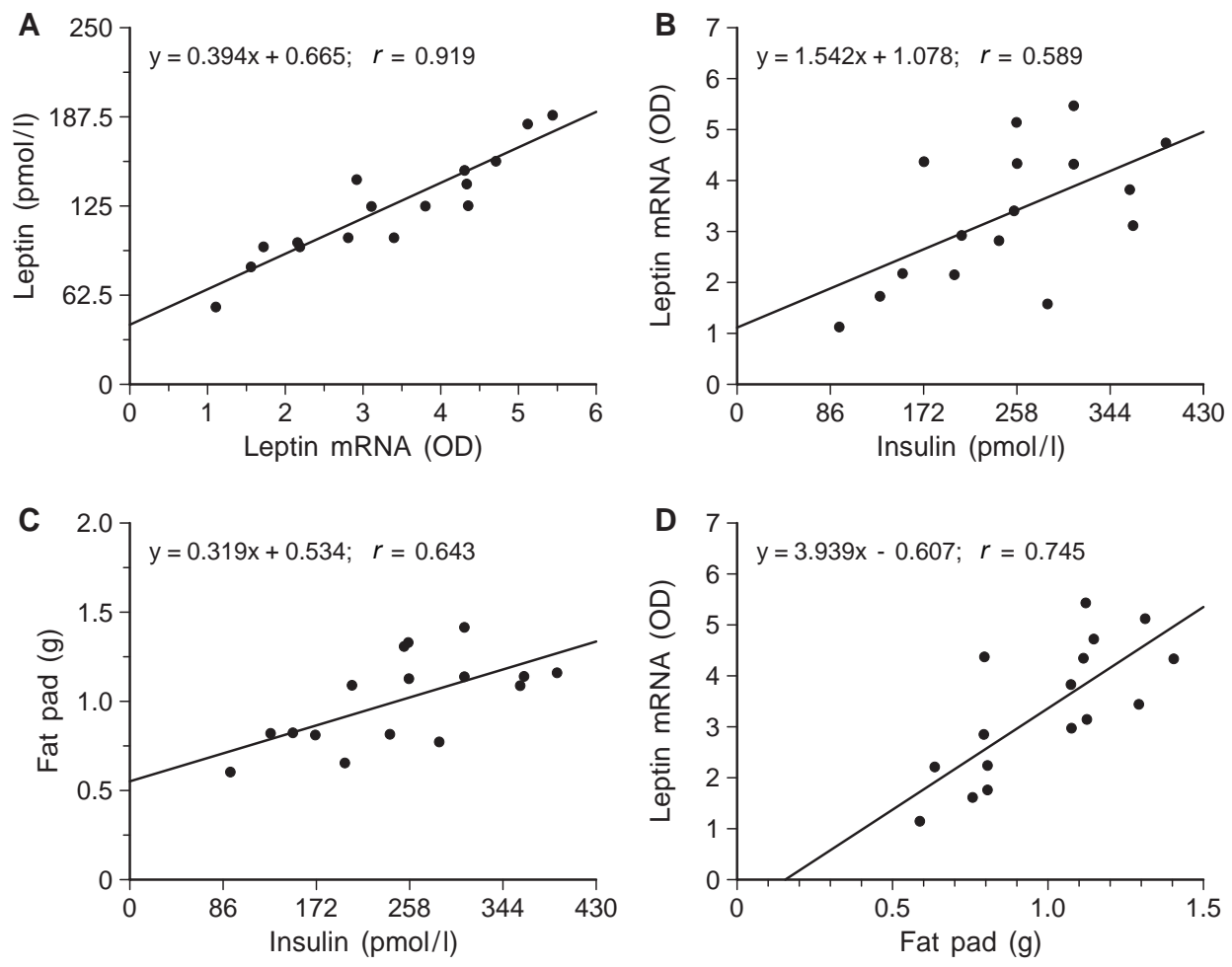

Fig. 2. Linear regression analysis with results of individual animals from all three treatment groups $(n=16)$. A Leptin mRNA vs serum leptin $(p<0.001)$, B Insulin vs leptin mRNA $(p<0.02)$, C Insulin vs epididymal fat pad weight $(p<0.01)$, D Fat pad weight vs leptin mRNA $(p<0.001)$. Two animals (one normal and one GH-treated) could not be included in this analysis because not enough blood was obtained during aortic puncture. OD, optical density (arbitrary units)

sion by exogenous IGF I in the GH-deficient patients was accompanied by suppressed insulin secretion.

How might exogenously administered IGF I reduce fat mass and leptin in our experimental animals? It is not very likely that IGF I acted directly on fat tissue by way of type 1 IGF receptors because rat adipocytes lack functional type 1 IGF receptors [32]. This agrees with in vitro data in white adipocytes where a direct effect of IGF I on leptin production could not be shown [18]. Since IGF I crossreacts, although poorly, with the insulin receptor of fat cells [33], an insulin receptor-mediated effect of the infused IGF I could be possible. This would not be compatible with decreased fat pad weights and suppression of leptin, since an insulin-like action would rather stimulate lipogenesis and thus fat pad weight and enhance leptin expression. Therefore, the reduction of the fat pad mass during IGF I infusion appears to be due rather to an indirect action of IGF I, leading to enhanced fat mobilization. One of the prominent hormonal changes during IGF I infusion in humans is suppression of insulin secretion [31, 34, 35]. Similarly, insulin secretion has been reported to

be suppressed by rhIGF I in rat pancreatic islets and islet cells in vitro $[36,37]$ as well as during shortterm infusion in fasted rats [38]. Rat islet cells contain type 1 IGF receptors [36, 37], and the inhibitory effect on insulin secretion appears to be mediated through activation by IGF I of phosphodiesterase 3B [37], resulting in decreased cellular cyclic AMP concentrations.

Although in our experiment the decrease of the serum insulin concentrations during rhIGF I infusion did not reach statistical significance when compared with the control rats, it was significant when compared with the GH-infused animals (whose insulin concentrations were not significantly different from those of the control animals). In an earlier study in normal rats, which had not yet addressed leptin regulation, we had already observed that rhIGF I infusion for 6 days greatly reduced fat pad weight and fat pad weight per $100 \mathrm{~g}$ of body weight and at the same time increased body weight gain per $100 \mathrm{~g}$ of body weight, findings which were confirmed by this study. In this previous experiment, serum insulin concentrations during rhIGF I infusion had dropped from $0.40 \pm 0.16$ to $0.186 \pm 0.11 \mathrm{pmol} / \mathrm{ml}(p=0.04)$. Together with the present data these data support the notion that long-term rhIGF I infusion suppresses insulin in rats, although this is difficult to prove with a single end-point determination of the serum insulin concentration in feeding animals. The correlation between serum insulin and fat pad mass as well as between serum insulin and leptin mRNA (Fig. 2) or serum leptin further suggests that decreased insulin secretion might be responsible for the decrease in fat pad mass 
by enhanced fat mobilization and thus for the decrease in leptin.

Enhanced fat mobilization might be expected to result in increased serum NEFA and glycerol concentrations. These increases, however, may be masked by enhanced NEFA oxidation leading to a fall of serum NEFA and TG, as observed in this study, and by increased gluconeogenesis from glycerol. The latter is consistent with the observation that serum glycerol concentrations did not increase but remained unchanged. Preferential oxidation of NEFA by skeletal muscle might explain why $\beta$-hydroxybutyrate resulting from NEFA oxidation in the liver tended to decrease rather than increase. The reduction of serum NEFA during rhGH infusion in the absence of changes in fat pad weight, serum TG and serum insulin might reflect more efficient TG resynthesis from NEFA released in adipose tissue within the triglyceride fatty acid cycle.

In summary, long-term exogenous IGF I infusion, in contrast to $\mathrm{GH}$, reduces fat pad mass in normal rats, most likely by suppressing insulin secretion and thus enhancing rat mobilization and NEFA oxidation. As a consequence, adipose tissue leptin mRNA and serum leptin concentrations fall. It is unlikely that the fall in leptin precedes or causes enhanced fat mobilization because decreased leptin would rather favor adipogenesis and increase food intake, which was not observed. In agreement with previous findings [20], GH does not appear to be a signal for leptin expression in the rat. The effects of GH on lipid metabolism clearly differ from those of exogenous IGF I, suggesting an IGF I-independent mechanism of GH action.

Acknowledgements. We would like to thank Mrs. M. Salman for competent secretarial help. The project was supported by the Swiss National Science Foundation (3200-046808.96) and by the COST Action B5.

\section{References}

1. Masuzaki H, Ogawa Y, Sagawa N et al. (1997) Nonadipose tissue production of leptin: Leptin as a novel placenta-derived hormone in humans. Nat Med 3: 1029-1033

2. Wang J, Liu R, Hawkins M, Barzilai N, Rossetti L (1998) A nutrient-sensing pathway regulates leptin gene expression in muscle and fat. Nature 393: 684-688

3. Zhang Y, Proenca R, Maffei M, Barone M, Leopold L, Friedman JM (1994) Positional cloning of the mouse obese gene and its human homologue. Nature 372: 425-423

4. Klein S, Coppack SW, Mohammed-Ali V, Landt M (1996) Adipose tissue leptin production and plasma leptin kinetics in humans. Diabetes 45: 984-987

5. Segal K, Landt M, Klein S (1996) Relationship between insulin sensitivity and plasma leptin concentration in lean and obese men. Diabetes 45: 988-991

6. Larsson H, Elmstahl S, Ahren B (1996) Plasma leptin levels correlate to islet function independently of body fat in postmenopausal women. Diabetes 45: 1580-1584
7. Caro JF, Sinha MK, Kolaczynski JW, Zhang PL, Considine RV (1996) Leptin: the tale of an obesity gene. Diabetes 45: 1455-1462

8. Tritos NA, Mantzoros CS (1997) Leptin: its role in obesity and beyond. Diabetologia 40: 1371-1379

9. Campfield LA, Smith FJ, Guisez Y, Devos R, Burn P (1995) Recombinant mouse ob protein: evidence for peripheral signal linking adiposity and central neural networks. Science 269: 546-549

10. Weigle DS, Bukowski TR, Foster DC et al. (1995) Recombinant ob protein reduces feeding and body weight in the ob/ob mouse. J Clin Invest 96: 2065-2070

11. Rentsch J, Levens N, Chiesi M (1995) Recombinant obgene product reduces food intake in fasted mice. Biochem Biophys Res Commun 214: 131-136

12. Pelleymounter MA, Cullen MJ, Baker MB et al. (1995) Effects of the obese gene product on body weight regulation in ob/ob mice. Science 269: 540-543

13. Saladin R, De Vos P, Guerre-Millo M et al. (1995) Transient increase in obese gene expression after food intake or insulin administration. Nature 377: 527-529

14. Cusin I, Sainsbury A, Doyle P, Rohner-Jeanrenaud F, Jeanrenaud $B$ (1995) The ob gene and insulin. A relationship leading to clues to the understanding of obesity. Diabetes 44: $1457-1470$

15. Leroy P, Dessolin S, Villageois P et al. (1996) Expression of ob gene in adipose cells. J Biol Chem 271: 2365-2368

16. Frederich RC, Löllmann B, Hamann A et al. (1995) Expression of ob mRNA and its encoded protein in rodents. Impact of nutrition and obesity. J Clin Invest 96: 1658-1663

17. MacDougald OA, Hwang C-S, Fan H, Lane MD (1995) Regulated expression of the obese product (leptin) in white adipose tissue and 3T3-L1 adipocytes. Proc Natl Acad Sci USA 92: 9034-9037

18. Hardie LJ, Guilhot N, Trayhurn P (1996) Regulation of leptin production in cultured mature white adipocytes. Horm Metab Res 28: 685-689

19. Rentsch J, Chiesi M (1996) Regulation of ob gene mRNA levels in cultured adipocytes. FEBS Lett 379: 55-59

20. Böni-Schnetzier M, Gosteli-Peter MA, Moritz W, Froesch ER, Zapf J (1996) Reduced ob mRNA in hypophysectomised rats is not restored by growth hormone $(\mathrm{GH})$, but further suppressed by exogenously administered Insulinlike Growth Factor (IGF) I. Biochem Biophys Res Commun 225: 296-301

21. Bianda TL, Glatz Y, Böni-Schnetzier M, Froesch ER, Schmid C (1997) Effects of growth hormone (GH) and insulin-like growth factor-I on serum leptin in GH-deficient humans. Diabetologia 40: 363-364

22. Ogawa Y, Masuzaki H, Isse N et al. (1995) Molecular cloning of rat obese cDNA and augmented gene expression in genetically obese Zucker fatty (fa/fa) rats. J Clin Invest 96: 1647-1652

23. Maniatis T, Fritsch EF, Sambrook J (1982) Extraction, purification and analysis of mRNA from eukaryotic cells. In: Molecular cloning, Cold Spring Harbor Laboratory, N. Y., USA, pp 196-205

24. Church GM, Gilbert W (1984) Genomic sequencing. Proc Natl Acad Sci USA 81: 1991-1995

25. Böni-Schnetzler M, Schmid CH, Meier PJ, Froesch ER (1991) Insulin regulates insulin-like growth factor I (IGF I) mRNA in rat hepatocytes. Am J Physiol 260:E846-E851

26. Eggstein M, Kreutz FH (1966) Eine neue Bestimmung der Neutralfette in Blutserum und Gewebe. Klinische Wochenschrift 44: 262-267

27. Zapf J, Walter H, Froesch ER (1981) Radioimmunological determination of insulin-like growth factors I and II in nor- 
mal subjects and in patients with growth disorders and extrapancreatic tumor hypoglycemia. J Clin Invest 68: $1321-1330$

28. Zapf J, Hauri C, Futo E, Hussain MA, Rutishauser J, Maack CA, Froesch ER (1995) Intravenously injected insulin-like growth factor (IGF) I/IGF binding protein-3 complex exerts insulin-like effects in hypophysectomized, but not in normal rats. J Clin Invest 95: 179-186

29. Mehls O, Ritz E, Hunziker E-B, Eggli P, Heinrich U, Zapf J (1988) Improvement of growth and food utilization by human recombinant growth hormone in uremia. Kidney Int 33: $45-52$

30. Carro E, Senaris R, Considine RV, Casanueva FF, Dieguez C (1997) Regulation of in vivo growth hormone secretion by leptin. Endocrinology 138: 2203-2206

31. Hussain MA, Schmitz O, Mengel A, Glatz Y, Christiansen JS, Zapf J, Froesch ER (1994) Comparison of the effects of growth hormone and insulin-like growth factor I on substrate oxidation and on insulin sensitivity in growth hormone-deficient humans. J Clin Invest 94: 1126-1133

32. Massague J, Czech MP (1982) The subunit structures of two distinct receptors for insulin-like growth factors I and II and their relationship to the insulin receptor. $\mathrm{J}$ Biol Chem 257: 5038-5045
33. Zapf J, Schoenle E, Froesch ER (1978) Insulin-like growth factors I and II: some biological actions and receptor binding characteristics of two purified constituents of nonsuppressible insulin-like activity of human serum. Eur J Biochem 87: 285-296

34. Guler H-P, Schmid CH, Zapf J, Froesch ER (1989) Effects of recombinant insulin-like growth factor I on insulin secretion and renal function in normal human subjects. Proc Natl Acad Sci USA 86: 2868-2872

35. Hussain MA, Schmitz O, Mengel A, Keller A, Christiansen JS, Zapf J, Froesch ER (1993) Insulin-like growth factor I stimulates lipid oxidation, reduces protein oxidation, and enhances insulin sensitivity in humans. J Clin Invest 92: 2249-2256

36. Van Schravendijk CFH, Heylen L, Van den Brande JL, Pipeleers DG (1990) Direct effect of insulin and insulinlike growth factor-I on the secretory activity of rat pancreatic Beta cells. Diabetologia 33: 649-653

37. Zhao AZ, Zhao H, Teague J, Fujimoto W, Beavo JA (1997) Attenuation of insulin secretion by insulin-like growth factor I is mediated through activation of phosphodiesterase 3B. Proc Natl Acad Sci USA 94: 3223-3228

38. Jacob R, Barrett E, Plewe G, Fagin KD, Sherwin RS (1989) Acute effects of insulin-like growth factor I on glucose and amino acid metabolism in the awake fasted rat. J Clin Invest $83: 1717-1723$ 